BUDGETING : Journal of Business, Management and Accounting

Volume 2, Nomor 1, Desember 2020

e-ISSN: 2715-2480

p-ISSN: 2715-1913

DOI : https://doi.org/10.31539/budgeting.v2i1.1223

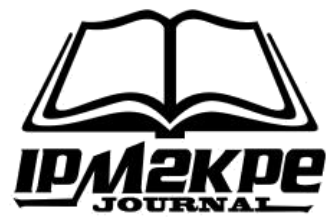

\title{
KONSTRUKSI LAPORAN KEUANGAN BERDASARKAN STANDAR AKUNTANSI KEUANGAN ENTITAS MIKRO, KECIL DAN MENENGAH (SAK EMKM)
}

\author{
Annisa Bulan Jasmine Yuwono ${ }^{1}$, Yulinartati ${ }^{2}$, Ibna Kamelia Fiel Afroh ${ }^{3}$ \\ Universitas Muhammadiyah Jember ${ }^{1,2,3}$ \\ bjpink24@gmail.com ${ }^{1}$
}

\begin{abstract}
ABSTRAK
Tujuan penelitian ini adalah menganalisis proses penyusunan laporan keuangan Salad Bulan, kendala-kendala yang dialami selama penyusunan laporan keuangan dan kesesuaian bentuk laporan keuangan dengan format laporan keuangan dalam SAK EMKM. Metode penelitian ini adalah deskriptif kualitatif dengan pengumpulan data, menganalisis data, menginterpretasikan data dan diakhiri dengan kesimpulan berdasarkan analisis data. Hasil penelitian menunjukkan bahwa penyusunan laporan keuangan oleh peneliti dapat menentukan jumlah kas sebesar Rp. 32.565 .000 dan penjualan Rp. 174.321.000. Simpulan, Salad Bulan belum menerapkan pelaporan keuangan yang sesuai dengan Standar Akuntansi Keuangan Entitas Mikro, Kecil dan Menengah (SAK EMKM) karena hanya dibuat berdasarkan kebutuhan dan pemahaman pemiliknya.
\end{abstract}

Kata Kunci: SAK EMKM, Standar Akuntansi Keuangan, UMKM

\section{ABSTRACT}

The purpose of this study was to analyze the process of preparing the Salad Bulan financial statements, the constraints experienced during the preparation of the financial statements and the conformity of the form of financial reports with the financial report format in SAK EMKM. This research method is descriptive qualitative by collecting data, analyzing data, interpreting data, and ending with conclusions based on data analysis. The results showed that the preparation of financial statements by researchers can determine the amount of cash as much as Rp. 32,565,000 and sales of Rp. 174,321,000. In conclusion, Salad Bulan has not implemented financial reporting in accordance with the Accounting Standards for Micro, Small, and Medium Finance because it is only made based on the owner's needs and understanding.

Keywords: SAK EMKM, Financial Accounting Standards, UMKM

\section{PENDAHULUAN}

Topik mengenai Usaha Mikro, Kecil dan Menengah (UMKM) telah menjadi salah satu faktor dalam perekonomian Indonesia saat ini. UMKM secara langsung mendorong pertumbuhan ekonomi untuk masyarakat. UMKM merupakan salah satu usaha yang banyak didirikan oleh masyarakat karena selain mengeluarkan modal yang 
tidak besar, kegiatan-kegiatannya juga telah membuka lapangan kerja baru untuk membantu masyarakat yang masih pengangguran dan belum menemukan pekerjaan. Penyerapan tenaga kerja baru oleh UMKM pun akan berdampak secara signifikan dalam menurunkan tingkat penganggura masyarakat di Indonesia. Selain itu, berwirausaha dengan membangun UMKM merupakan pekerjaan yang sangat menyenangkan karena selain mempunyai kreatif yang tinggi, berwirausaha juga tidak terikat dengan orang lain dengan mendirikan suatu usaha tanpa terasa sudah membantu perekonomian Indonesia.

Berdasarkan UU No. 20 tahun 2008, kriteria yang tepat mengenai UKM ada tiga macam yaitu: 1) usaha mikro memiliki kekayaan bersih tidak lebih dari Rp. 20.000.000 dan penjualan tahunan tidak lebih dari Rp. 300.000.000; 2) usaha kecil memiliki kekayaan bersih Rp. 50.000.000 sampai dengan Rp. 500.000.000 dan penjualan tahunan antara Rp. 300.000.000 sampai dengan Rp. 2.500.000.000; 3) usaha menengah memiliki kekayaan bersih antara Rp. 500.000.000 sampai dengan Rp. 10.000.000.000 dan penjualan bersih tahunan antara Rp. 2.500.000.000 sampai dengan Rp. 50.000.000.000 (Raja et al., 2010).

Berdasarkan sensus ekonomi nasional, populasi UMKM Jawa Timur tumbuh dari 6,8 juta yaitu pada tahun 2012, menjadi 9,59 juta pada 2017. Peningkatan UMKM Kabupaten Jember sendiri juga bertambah banyak dari tahun ke tahun. Dengan adanya data tersebut maka dapat dikatakan bahwa UMKM merupakan faktor yang penting dalam pertumbuhan perekonomian Jawa Timur.

Hal ini sangat cocok dengan keadaan di lapangan, dimana masyarakat modern ini banyak sekali memiliki kelebihan kreatifitas sehingga mereka bisa menciptakan peluang-peluang baru dengan menciptakan UMKM diberbagai bidang. Kabupaten Jember memiliki beberapa bidang antaranya adalah bidang fashion, rumah tangga, minuman, makanan, kerajinan tangan, aneka bahan dasar, aneka batik dan produk lainnya. Hal yang paling banyak diminati pelaku usaha UMKM ada pada bidang pengolahan makanan dan minuman.

Saat ini makanan sehat semestinya menjadi bagian dari gaya hidup semua orang. Namun, tingginya tingkat stress yang dialami oleh kaum pekerja yang ada membuat sebagian orang mencari kenikmatan lewat makanan. Kuliner menjadi kegemaran banyak orang tanpa memperdulikan kesehatan makanan itu sendiri. Kebanyakan orang 
lebih mengutamakan makanan dengan rasa yang lezat dan tidak sehat daripada makanan yang sehat. Setelah selesai dengan makanan tersebut timbullah penyesalan karena terdiagnosa mengalami penyakit misalnya diabetes, darah tinggi hingga penyakit jantung. Hanya karena mengabaikan makanan sehat, seseorang berpotensi kehilangan masa depannya dan tidak dapat menikmati hasil kerja kerasnya selama bertahun-tahun. Pentingnya edukasi mengenai makanan sehat dapat meningkatkan kualitas hidup seseorang, diiringi dengan komitmen untuk menjalani pola makan yang teratur.

Pelaku usaha UMKM di Kabupaten Jember telah banyak menyadari hal tersebut. Oleh karena itu, di akhir tahun 2017 sampai dengan pada tahun 2019 ini banyak sekali timbulnya penjual salad. Salad merupakan makanan yang banyak diminati masyarakat, selain karena salah satu makanan yang menyehatan, salad juga dianggap sebagai menu alternatif untuk para wanita yang ingin menjalankan program diet namun tetap ingin sehat. Diketahui dari aplikasi Go-jek dari tahun 2017-2019 (update September 2019) sudah banyak sekali pengembang usaha salad, selain mudah untuk dibuat, peluang usaha ini juga sedang naik daun. Ada puluhan nama terdaftar yang menawarkan menu salad sebagai menu utamanya dan ada sebagian yang menjadikannya menu tambahan atau pendamping.

UMKM pengolah pangan salad yang eksis di Kabupaten Jember salah satunya adalah Salad Bulan. Usaha ini menyediakan berbagai olahan menu sehat antaranya salad buah, salad sayur dan ada juga menu dessert brownies yang juga dicampurkan dengan buah alpukat sehingga masyarakat yang menikmatinya tetap bisa mendapatkan sensasi makan kue brownies tetapi tetap sehat dengan campuran buah alpukat.

\section{KAJIAN TEORI}

\section{Kontruksi}

Kata konstruksi ini dalam kenyataannya adalah konsep yang cukup sulit untuk dipahami dan disepakati kata konstruksi mempunyai beragam interpretasi, tidak dapat didefinisikan secara tunggal, dan sangat tergantung pada konteksnya. Beberapa definisi konstruksi berdasarkan konteksnya perlu dibedakan atas dasar proses, bangunan, kegiatan, bahasa dan perencanaan.

Berdasarkan uraian diatas definisi konstruksi dalam konteks hubungannya dengan penelitian ini memiliki arti suatu bentuk, tata cara atau secara lebih luas 
merupakan pola-pola hubungan yang ada di dalam suatu sistem yang membentuk suatu proses kerja dalam hal ini proses pembuatan atas laporan keuangan. Maka konstruksi dalam penelitian ini yaitu berupaya untuk melakukan pembuatan atas laporan keuangan yang sesuai dengan pernyataan Standar Akuntansi Keuangan Entitas Mikro, Kecil dan Menengah (SAK EMKM).

\section{Pengertian Teori Entitas}

Akuntansi merupakan pengukuran atas nilai-nilai hasil operasi yang dilakukan oleh suatu entitas tertentu, yang terpisah dan harus dibedakan dengan pemilik. Transaksi yang dicatat adalah transaksi perusahaan yang harus dipisahkan dan dibedakan dengan transaksi pemilik perusahaan. Dengan kata lain akuntan membedakan dan memisahkan antara transaksi personal pemilik dengan transaksi perusahaan.

\section{Definisi Wirausaha}

Pengertian kewirausahaan itu sendiri berkembang sejalan dengan evaluasi pemikiran para ahli ekonom di dunia barat kemudian menyebar ke negara-negara lain termasuk ke Indonesia. Di negara kita sendiri, konsep enterpreneurship tersebut dialih bahasakan sebagai kewiraswastaan atau kewirausahaan, sementara enterpreneurship sebagai wirausaha.

Wirausahawan adalah orang yang memiliki seni dan ketrampilan tertentu dalam menciptakan usaha yang baru. Wirausahawan memiliki pemahaman sendiri akan kebutuhan tersebut. Wirausahawan akan mempengaruhi masyarakat dengan membuka usaha baru, tetapi pada saat yang sama ia dipengaruhi oleh masyarakat untuk mengenali kebutuhan dan memenuhinya melalui ketajaman manajemen sumber daya.

Menurut Saiman (2009), wirausaha (enterpreneur) adalah seorang yang memutuskan untuk memulai suatu bisnis, sebagai pewaralaba (franchisor) menjadi terwaralaba (franchisee), memperluas sebuah perusahaan, membeli sebuah perusahaan yang sudah ada atau barangkali meminjam uang untuk memproduksi suatu produk baru atau menawarkan jasa suatu jasa baru serta merupakan manajer dan penyandang resiko. 


\section{Definisi Entitas Mikro, Kecil dan Menengah (EMKM)}

Pengertian EMKM dalam SAK EMKM (IAI, 2016) yaitu entitas tanpa akuntabilitas publik yang signifikan. Sebagaimana didefinisikan dalam Standar Akuntansi Keuangan Entitas Tanpa Akuntabilitas Publik (SAK ETAP), yang memenuhi definisi dan kriteria usaha mikro, kecil dan menengah diatur dalam peraturan perundang-undangan yang berlaku di Indonesia, setidaknya selama dua tahun berturutturut.

Menurut Undang-Undang Nomor 20 tahun 2008 definisi UMKM dapat dijabarkan secara terperinci sebagai berikut: a) usaha mikro adalah usaha ekonomi produktif milik perseorangan dan atau badan usaha perseorangan yang memenuhi kriteria usaha mikro sebagaimana diatur dalam undang-undang ini; b) usaha kecil adalah usaha ekonomi produktif yang berdiri sendiri, yang dilakukan oleh orang perseorangan atau badan usaha yang bukan merupakan anak perusahaan atau bukan cabang dari usaha menengah atau usaha besar yang memenuhi kriteria usaha kecil sebagaimana dimaksud dalam undang-undang ini; c) usaha menengah adalah usaha ekonomi produktif yang berdiri sendiri, yang dilakukan oleh orang perorangan atau badan usaha yang bukan merupakan anak perusahaan atau cabang perusahaan yang dimiliki, dikuasai, atau menjadi bagian, baik langsung maupun tidak langsung dengan usaha kecil atau usaha besar dengan jumlah kekayaan bersih atau hasil penjualan tahunan sebagaimana diatur dalam UU No. 20 tahun 2008.

\section{Standar Akuntansi Keuangan Entitas Mikro, Kecil dan Menengah}

Ikatan Akuntan Indonesia telah menerbitkan SAK EMKM dan disahkan oleh Dewan Standar Akuntansi Keuangan pada tanggal 18 Mei 2016. SAK EMKM berlaku secara efektif untuk penyusunan laporan keuangan yang dimulai tanggal 1 Januari 2018. Berdasarkan ruang lingkup SAK EMKM, maka standar ini dimaksudkan untuk entitas mikro, kecil dan menengah serta dapat digunakan untuk entitas yang tidak memenuhi kriteria SAK ETAP.

\section{Definisi dan Komponen Laporan Keuangan Entitas Mikro, Kecil dan Menengah}

Analisis laporan keuangan dimulai dengan pemahaman tentang laporan keuangan, yaitu neraca, laba rugi, dan laporan arus kas (Prihadi, 2011). Menurut Kasmir 
(2016), terdapat dua metode analisis laporan keuangan yang digunakan, yaitu analisis horizontal dan analisis vertikal.

Menurut IAI (2016), komponen laporan keuangan untuk entitas mikro, kecil dan menengah terdiri dari: laporan posisi keuangan, laporan laba rugi dan catatan atas laporan keuangan.

\section{METODE PENELITIAN}

Metode penelitian ini adalah kualitatif deskriptif yang digunakan dalam penelitian ini dimaksutkan untuk mendeskripsikan dan menggambarkan mengenai penerapan SAK EMKM yang ditinjau dari laporan keuangan yang dibuat oleh UMKM Salad Bulan. Unit produksi Salad Bulan Jember terletak di Jalan Kalimantan (Pujasera Kalimantan), Kelurahan Sumbersari, Kecamatan Sumbersari, Kabupaten Jember, Jawa Timur, 68121.

Penelitian ini menggunakan jenis data primer dan sekunder. Sumber data yang digunakan dalam penelitian ini yaitu bukti-bukti transaksidari UMKM Salad Bulan Jember. Bukti-bukti transaksi ini berupa nota pembeliandan nota penjualan. Pada penelitian ini peneliti menggunakan metode analisis data kualitatif deskriptif. Peneliti menggunakan dan menjelaskan tentang hal-hal yang berkaitan dengan laporan keuangan UMKM Salad Bulan. Berikut adalah langkah-langkahnya: 1) pengumpulan data akan memperoleh sumber data dari proses wawancara, dokumentasi, dan penelusuran online. Subjek penelitian yang terlibat langsung yaitu pemilik UMKM Salad Bulan yang sekaligus sebagai pengelola data dan informasi; 2) konstruksi data yang telah terkumpul akan di konstruksi untuk menjawab rumusan masalah pada penelitian ini. Tahap-tahap konstruksi terdiri dari: a) jurnal; b) buku besarneraca saldo; c) laporan keuangan; d) laporan posisi keuangan/neraca; e) laporan laba/rugi; f) catatan atas laporan keuangan.

\section{HASIL PENELITIAN}

\section{Laporan Posisi Keuangan}

Laporan keuangan mencakup akun-akun seperti kas, persediaan, aset tetap, utang usaha dan ekuitas. Perusahaan menyajikan akun dan bagian dari akun laporan posisi keuangan jika penyajiannya tersebut relevan untuk memahami posisi keuangan perusahaan. Di dalam SAK EMKM tidak menentukan urutan atau format terhadap 
akun-akun yang disajikan. Perusahaan dapat menyajikan akun-akun aset berdasarkan urutan likuiditas dan akun-akun likuiditas berdasarkan jatuh tempo.

Tabel 1.

Laporan Posisi Keuangan

\begin{tabular}{|c|c|c|}
\hline \multicolumn{3}{|c|}{$\begin{array}{c}\text { SALAD BULAN } \\
\text { LAPORAN POSISI KEUANGAN } \\
\text { Periode 2018-2019 }\end{array}$} \\
\hline ASET & \multicolumn{2}{|c|}{ NILAI KEUANGAN } \\
\hline \multicolumn{3}{|l|}{ Aset lancar } \\
\hline Kas & Rp. 32.565 .000 & \\
\hline ATK & 371.000 & \\
\hline Total aset lancar & & Rp. 32.586 .000 \\
\hline \multicolumn{3}{|l|}{ Aset tetap } \\
\hline Peralatan & Rp. 3.342 .000 & \\
\hline Total aset tetap & & Rp. 3.342 .000 \\
\hline JUMLAH ASET & & Rp. 36.278.000 \\
\hline LIABILITAS & & - \\
\hline Total liabilitas & & - \\
\hline \multicolumn{3}{|l|}{ EKUITAS } \\
\hline Modal Awal & & Rp. 10.000.000 \\
\hline Laba & Rp. 30.078.000 & \\
\hline \multirow[t]{2}{*}{ Prive } & Rp. 3.800 .000 & \\
\hline & & Rp. 26.278.000 \\
\hline JUMLAH LIABI & & Rp. 36.278.000 \\
\hline
\end{tabular}

\section{Laporan Laba Rugi}

Laporan laba rugi dapat mencakup akun-akun pendapatan, beban keuangan dan baban pajak. Perusahaan menyajikan akun dan bagian dari akun dalam laporan laba rugi jika penyajiannya tersebut relevan untuk memahami kinerja keuangan perusahaan.

Tabel 2.

Laporan Laba Rugi

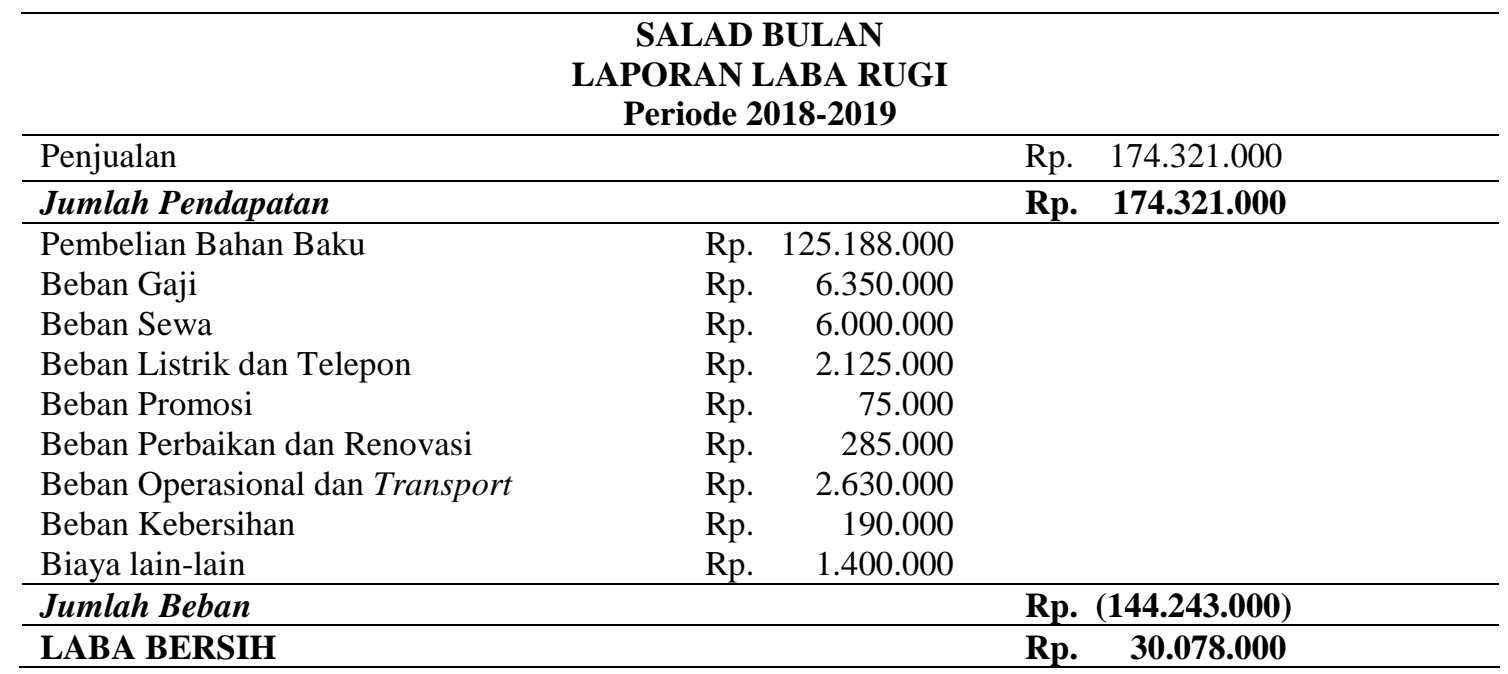




\section{Catatan Laporan Keuangan}

Catatan atas laporaan keuangan ini mendasari informasi yang disajikan dalam catatan atas laporan keuangan dan bagaimana penyajiannya atau dengan kata lain catatan atas laporan keuangan ini memberikan informasi mengenai laporan keuangan bahwa telah disusun berdasarkan SAK EMKM, kebijakan akuntansi, informasi tambahan dan rincian akun-akun tertentu yang menjelaskan transaksi penting. Jenis informasi tambahan dan rincian yang disajikan bergantung pada jenis kegiatan usaha yang dilakukan oleh perusahaan. Catatan atas laporan keuangan disajikan secara teratur sepanjang hal tersebut praktis, setiap akun dalam laporan keuangan merujuk silang ke informasi terkait dalam catatan atas laporan keuangan.

Tabel 3.

Catatan Laporan Keuangan

\begin{tabular}{l} 
SALAD BULAN \\
CATATAN ATAS LAPORAN KEUANGAN \\
Periode 2018-2019 \\
\hline UMUM \\
UMKM Salad Bulan merupakan usaha jenis makanan ringan yang mulai didirikan pada tahun 2018. \\
Usaha ini termasuk dalam jenis Usaha Mikro, Kecil dan Menegah (UMKM). UMKM Salad Bulan \\
terletak di Jalan Kalimantan (Pujasera Kalimantan), Kelurahan Sumbersari, Kecamatan Sumbersari, \\
Kabupaten Jember, Provinsi Jawa Timur. \\
IKHTISAR KEBIJAKAN AKUNTANSI \\
a. Pernyataan Kepatuhan \\
Laporan keuangan disusun berdasarkan Standar Akuntansi Keuangan Entitas Mikro, Kecil dan \\
Menengah. \\
b. Dasar Penyusunan \\
Dasar penyusunan laporan keuangan disajikan dengan mata uang rupiah. \\
c. Pernyataan Kepatuhan \\
Laporan keuangan disusun berdasarkan Standar Akuntansi Keuangan Entitas Mikro, Kecil dan \\
Menengah. \\
d. Dasar Penyusunan \\
Dasar penyusunan laporan keuangan disajikan dengan mata uang rupiah. \\
e. Pengakuan Pendapatan dan Beban \\
Pendapatan penjualan diakui pada saat terjadinya penjualan kepada \\
konsumen. Beban diakui pada saat terjadinya beban. \\
KaS berjumlah Rp. 32.565.000
\end{tabular}

\section{SALDO LABA}

Saldo laba merupakan akumulasi selisih pendapatan dan beban setelah dikurangi dengan distribusi pemilik.

\section{PENDAPATAN PENJUALAN}

Penjualan berjumlah Rp. 174.321.000 


\section{PEMBAHASAN}

Hasil penelitian pada Salad Bulan menunjukkan bahwa UMKM ini belum menerapkan pelaporan keuangan yang sesuai dengan Standar Akuntansi Keuangan Entitas Mikro, Kecil dan Menengah (SAK EMKM). Bukan hanya Salad Bulan, ternyata masih banyak UMKM yang belum menggunakan standar laporan keuangan yang memadai. Hal ini dapat terlihat dari hasil penelitian yang dilakukan oleh Alfitri et al., (2014), Muchid (2015) dan Susanto (2011). Ketiga penelitian tersebut menunjukkan bahwa banyak UKM belum menerapkan dan menyusun laporan keuangan sesuai dengan Standar Akuntansi Keuangan yang berlaku umum. Alasan UMKM belum menerapkan standar akuntansi tersebut adalah karena keterbatasan waktu, kurangnya pemahaman tentang akuntansi dan kurangnya sumber daya manusia. Sehingga laporan keuangan yang dibuat oleh UMKM masih sangat sederhana.

Standar Akuntansi Keuangan Entitas Mikro Kecil dan Menengah (SAK EMKM) lebih mudah dibandingkan dengan SAK ETAP (Standar Akuntansi Keuangan untuk Entitas Tanpa Akuntabilitas Publik) karena terdiri dari tiga komponen yaitu laporan posisi keuangan, laporan laba rugi dan catatan atas laporan keuangan. Laporan posisi keuangan adalah laporan yang menggambarkan posisi keuangan suatu perusahaan pada tanggal tertentu. Laporan posisi keuangan menyajikan akun-akun aktiva, pasiva dan ekuitas. Adapun laporan laba rugi adalah laporan yang menunjukkan kemampuan perusahaan perusahaan atau entitas bisnis menghasilkan keuntungan pada suatu periode waktu tertentu, misalnya satu bulan atau satu tahun. Kemudian catatan atas laporan keuangan merupakan laporan yang berisi informasi tambahan dan rincian yang disajikan berdasarkan jenis kegiatan usaha yang dijalankan oleh entitas (IAI, 2016). Sedangkan SAK ETAP terdiri dari lima Komponen yaitu, laporan posisi keuangan, laporan laba rugi, laporan arus kas, laporan perubahan ekuitas dan catatan atas laporan keuangan. Untuk UKM, menyusun laporan keuangan dengan lima komponen bagi mereka mungkin terlalu sulit. Oleh karena itu, SAK EMKM diterbitkan untuk memudahkan UKM dalam menyusun laporan keuangan (Nurlaila, 2018).

IAI (2016) menyatakan bahwa SAK EMKM merupakan standar yang jauh lebih sederhana jika dibandingkan dengan SAK ETAP. Misalnya, dari segi teknikal, SAK EMKM murni menggunakan pengukuran biaya historis sehingga EMKM cukup mencatat aset dan liabilitasnya sebesar biaya perolehan. IAI menyatakan bahwa Undang 
Undang No. 20 Tahun 2008 tentang Usaha, Mikro, Kecil dan Menengah dapat dijadikan acuan dalam mendefinisikan dan memberikan rentan kualitatif EMKM.

Mendirikan sebuah usaha, tentunya harus mempunyai catatan administrasi. Catatan administrasi ini dapat berupa laporan keuangan. Masih banyak UKM yang belum menyusun laporan keuangan yang sesuai dengan standar. Rata-rata laporan keuangan yang disusun masih sangat sederhana. Padahal dengan menyusun laporan keuangan para usahawan bisa mengetahui pengelolaan keuangan yang baik. Pengelolaan keuangan yang baik salah satunya dengan membuat laporan keuangan. Maka dari itu, Ikatan Akuntan Indonesia menerbitkan SAK EMKM. Standar ini lebih memudahkan entitas untuk menyusun laporan keuangan. Alasan pergantian dari SAK ETAP menjadi SAK EMKM adalah mayoritas entitas mikro, kecil dan menengah di Indonesia sulit mendapatkan akses untuk ke perbankan dan sumber pendanaan lainnya. Kondisi ini dapat terjadi karena EMKM tidak memiliki laporan keuangan yang memadai dan sesuai dengan standar di industri keuangan, sehingga untuk menambah pendanaan, EMKM sangat kesulitan dan akhirnya tidak dapat melanjutkan usahanya (Nurlaila, 2018).

Tujuan laporan keuangan yang disajikan oleh suatu entitas dapat diperinci sebagai berikut: 1) untuk memberikan informasi keuangan yang dapat dipercaya mengenai sumber-sumber ekonomi dan kewajiban serta modal perusahaan; 2) untuk memberikan informasi yang dapat dipercaya mengenai perubahan sumber-sumber ekonomi perusahaan yang timbul dalam aktivitas usaha demi memperoleh laba; 3) untuk memberikan informasi keuangan yang membantu para pemakai laporan untuk mengestimasi potensi perusahaan dalm menghasilkan laba masa depan; 4) untuk memberikan informasi keuangan yang membantu para pemakai laporan ketika mengestimasi potensi perusahaan dalam menghasilkan laba; 5) untuk mengungkapkan sejauh mungkin informasi lain yang berhubungan dengan laporan keuangan yang relevan untuk kebutuhan pemakai laporan, seperti informasi mengenai kebijakan akuntasi yang dianut perusahaan; 6) untuk memberikan informasi penting lainnya mengenai sumber-sumber ekonomi dan kewajiban, seperti informasi tentang aktivitas pembiayaan dan investasi (IAI, 2016). 


\section{SIMPULAN}

Berdasarkan pembahasan di atas dapat disimpulkan bahwa pencatatan dan penyusunan laporan keuangan masih sangat sederhana sesuai kebutuhan serta pemahaman pemilik. Artinya Salad Bulan belum menerapkan pelaporan keuangan sesuai dengan Standar Akuntansi Keuangan Entitas Mikro, Kecil dan Menengah (SAK EMKM). Pemilik menyadari bahwa pentingnya pencatatan dan penyusunan laporan keuangan untuk keberlangsungan usaha.

\section{DAFTAR PUSTAKA}

Alfitri, A., Ngadiman, N., \& Sohidin, S. (2014). Penerapan Standar Akuntansi Keuangan Entitas Tanpa Akuntabilitas Publik (SAK-ETAP) pada Usaha Mikro Kecil Menengah (UMKM) Perajin Mebel Desa Gondangsari Kecamatan Juwiring Kabupaten Klaten. Jupe UNS, 2(2), 135-147

Ikatan Akuntan Indonesia. (2016). Standar Akuntansi Keuangan Entitas Mikro Kecil dan Menengah. Jakarta : Dewan Standar Akuntansi Keuangan Indonesia

Kasmir, K. (2014). Analisis Laporan Keuangan. Jakarta: Raja Grafindo

Muchid, A. (2015). Penyusunan Laporan Keuangan Berdasarkan Standar Akuntansi Keuangan Entitas Tanpa Akuntabilitas Publik (SAK ETAP) pada UD Mebel Novel L Banyuwang. Skripsi. Universitas Jember

Nurlaila, N. (2018). Penerapan Standar Akutansi Keuangan Entitas Mikro Kecil dan Menengah (SAK EMKM) pada Sukma Cipta Ceramic Dinoyo Malang. Malang : UIN Malang

Prihadi, T. (2011). Analisis Laporan Keuangan Teori dan Aplikasi. Jakarta: PPM Raja, O., Jalu, F., \& D'ral, V. (2010). Kiat Sukses Mendirikan dan Mengelola UMKM. Jakarta: EL Press

Saiman, L. (2009). Kewirausahaan : Teori, Praktik dan Kasus-Kasus. Jakarta: Salemba Empat

Susanto, E. (2011). Penerapan Standar Akuntansi Keuangan untuk Entitas Tanpa Akuntabilitas Publik (SAK ETAP) di UMKM Kelurahan Mojosongo Kecamatan Jebres Kota Surakarta. Skripsi. Universitas Sebelas Maret Surakarta 